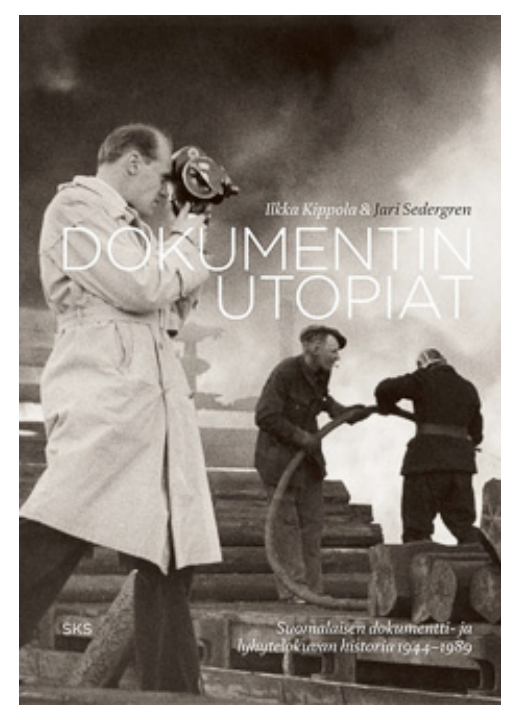

\section{ELOKUVA UTOPIOIDEN PALVELUKSESSA}

Jari Sedergren ja Ilkka Kippola (2015) Dokumentin utopiat: Suomalaisen dokumentti- ja lyhytelokuvan historia 1944-1989. Suomalaisen Kirjallisuuden Seura. 680 sivua.
Dokumentin utopiat on jatko-osa 2009 julkaistulle Dokumentin ytimessä: Suomalaisen dokumentti-ja lyhytelokuvan historia 1904-1944 -teokselle (SKS). Se jatkaa Kansallisessa audiovisuaalisessa instituutissa tutkijoina työskentelevien Jari Sedergrenin ja Ilkka Kippolan urakkaa, läpileikkausta suomalaisen dokumentti-ja lyhytelokuvan sekä dokumenttielokuvakulttuurin historiaan - elokuviin, tekijöihin ja taustoihin - aivan elokuvan alkumetreiltä asti 1990-luvun taitteeseen.

Elokuvan rinnalla kulkee kulttuurinen ja poliittinen kehys, jota värittivät etenkin suhde Neuvostoliittoon, hyvinvointiyhteiskunnan rakentaminen, vasemmistolaisuus sekä maan taloudellinen vaurastuminen, jotka kaikki jättivät jälkensä myös aikansa dokumenttielokuvaan. Kirjan erityinen ansio onkin dokumenttielokuvien ja elokuvakulttuurin liittäminen laajempaan yhteiskunnalliseen kontekstiin, kuten tuotantoyhtiöiden ja -kulttuurin vaiheisiin sekä poliittisiin ja ideologisiin keskusteluihin ja kuohuntoihin. Aineistona teoksessa on käytetty paitsi elokuvia, myös monimuotoisia kirjallisia lähteitä, kuten arvioita ja muuta elokuvia koskevaa lehdistökirjoittelua, kirjallisuutta, mietintöjä, Valtion elokuvatarkastamon päätöksiä, tuotantoyhtiöiden taustadokumentteja ja haastatteluja.

Jos dokumentti- ja lyhytelokuvan kenttää olivat 1900-luvun alussa hallinneet matkailuelokuvan, kansatieteellisen elokuvan, teollisuus-, uutis- ja propagandaelokuvan "genret" (ks. Sedergren \& Kippola 2009), sodan jälkeisinä vuosikymmeninä dokumentti- ja lyhytelokuva avautui ja monipuolistui sekä muodon että si- sällön suhteen. Sodan jälkeisen Suomen dokumentti- ja lyhytelokuvatuotanto kukoisti, sillä aina vuoteen 1964 voimassa oli veronalennus pääelokuvan pääsylipusta, kun "alkukuvana" esitettiin enintään 200 metriä pitkä, tiede-, opetus- tai taidefilmi tai kansallista elinkeinoelämää esittelevä lyhytelokuva. Näitä niin sanottuja veronalennuskuvia halveksittiin pitkään ja ne nähtiin lähinnä raakamateriaalina uusille tekijöille ja elokuville. "Arkistofilmeiksi" kutsuttujen elokuvien kulttuurihistoriallinen arvo ehkä tunnustettiin, mutta alkuperäiset tekijät ja kuvien elokuvahistoriallinen arvo eivät juuri herättäneet kiinnostusta. (S. 44-45.)

Sodan jälkeisten vuosikymmenten dokumentti-ja lyhytelokuviin tallentuivat jälleenrakennuksen ajan propagandaa hipova optimistinen eetos, sisä- ja ulkopolitiikan myrskyisät vaiheet sekä modernisoituvan maan ponnistukset. Sodan menetysten ja pettymysten jälkeen elokuvantekijöiden mielessä väikkyi, kuten Sedergren ja Kippola kirjoittavat, "hyvinvoiva, edistynyt, parempi ja onnellisempi maailma" (s. 21), ja dokumenttielokuva sai kunnian luoda uskoa tähän maailmaan, visualisoida ja äänittää "todelliseksi edistyksen ja valistuksen hyväksi määrittelemät arvot". Dokumentti-ja lyhytelokuvat antoivat katsojilleen lupauksen modernin elämäntavan ja hyvinvoinnin lisääntymisestä, uskon valoisampaan tulevaisuuteen. Tätä dokumenttielokuvan roolia korostaen Sedergren ja Kippola ovatkin nostaneet teoksen nimeen juuri utopiat, joita valjastettiin moneen - Suomi-kuvan kirkastamiseen, yritysten imagonrakennukseen, uusien keksintöjen ja tieteenalojen kuvauksiin, am- 
mattiyhdistysliikkeen toiminnan sekä valtion ponnistusten esittelyyn.

Dokumentti- ja lyhytelokuvakulttuurin muutoksista nostetaan esiin useita käännekohtia, kuten säännöllisten televisiolähetysten alkaminen vuonna 1958, josta parin vuoden kuluttua alkoi sekä fiktiivisen että dokumenttielokuvan alamäki. Veronalennuspolitiikan loppuminen vuonna 1964 aiheutti suuren notkahduksen kotimaisten dokumentti- ja lyhytelokuvien tuotannossa. Järjestelmän alasajoa kannatti muun muassa Helge Miettunen, jonka dokumenttielokuvaakin sivuava väitöskirja Johdatus elokuvan estetiikkaan, ensimmäinen elokuvatutkimuksen alan väitös Suomessa, julkaistiin vuonna 1949. ${ }^{1}$

1970-luvulta alkoi kuitenkin dokumentti- ja lyhytelokuvan uusi nousu valtiontuen kannustamana, kun uusi elokuvatukijärjestelmä perustettiin. Dokkarit tulivat osaksi television ohjelmistoa ja uuden aallon sekä cinéma véritén kipinät laskeutuivat myös kaukaiseen Pohjolaan. Julkisuutta ja uusia yleisöjä tekijöille toivat myös elokuvafestivaalit ja -palkinnot, joista arvostetuimpiin kuuluivat vuodesta 1944 jaetut Jussi-palkinnot.

1980-luvun "uusia tuulia" ja dokumenttielokuvan kriisiä käsitellään myös kirjan loppupuolella. Myöhemmin dokumenttielokuvaohjaajana tunnetuksi tullut Mikko Piela raportoi Filmihullussa vuonna 1982 Tampereen elokuvajuhlilta "dokumentin rappiosta", joka hänen tulkintansa mukaan liittyi siihen, että "filmiväki on ryhtynyt sepittämään". Hän kirjoittaa dokumentin umpikujaa käsittelleestä festivaaliklubista näin: "Ulvontaa, tupakansavua, juomaveikkojen kalvakkaita kasvoja, infernaalista karjuntaa - ei suinkaan ja kuitenkin: Tunnelmassa aisti krampinomaisen kouristuneisuuden, joka vain odotti sopivaa hetkeä lauetakseen Rauta-ajan hääkohtauksen kaltaiseen tympeään irstauteen." (S. 574.) 1980-luvun myötä todellisuuden "tallentamisen" korvasivat todellisuuden postmoderni pirstaloituminen, muistin monitahoisuuden ja ristiriitaisuuden kuvaukset sekä elokuvantekijöiden henkilökohtaisten kokemusten käsittely.

\footnotetext{
1 Miettunen toimi myöhemmin muun muassa Kinolehden päätoimittajana ja Yleisradion ohjelmatoiminnan suunnittelupäällikkönä.
}

Teoksessa esitellään laaja joukko erilaisia dokumentti- ja lyhytelokuvan lajeja, jotka hallitsivat etenkin veronalennusaikaa, kuten uutisfilmit, matkailuelokuvat, teollisuuselokuvat, tilauselokuvat, opetuselokuvat ja tiedotuskuvat, joilla paitsi julkiset laitokset myös yritykset ja seurat esittelivät toimintaansa. Näiden lisäksi esiin nousevat valistuselokuvat, urheiluelokuvat, musiikkielokuvat ja muut kulttuurin ilmiöitä esiin tuovat filmit sekä tiede-elokuvat, joiden erottaminen opetus- ja valistuselokuvista oli ajoittain vaikeaa. Nämä rajalinjat olivat ylipäätään jatkuvassa muutoksessa, ja niitä taivutettiin moneen tarkoitukseen. Lajeja avataan teoksen temaattisesti järjestetyissä alaluvuissa, mutta joukkoon mahtuu myös suomalaista dokumenttielokuvan teorianmuodostusta, propagandan ja elokuvasensuurin, kansatieteellisen elokuvan, taistelevan dokumentin sekä televisiodokumentin vaiheita. Sivumäärällisesti teoksen pääpaino on 1940-70-lukujen tapahtumissa.

Sedergrenin ja Kippolan kunnianhimoisena tavoitteena on tuoda dokumenttielokuva osaksi suomalaista elokuvahistorian kaanonia, josta se on tavallisesti sysätty sivuun. Tässä kirja onnistuu loistavasti, vaikka sen annille olisi toivonutkin enemmän julkisuutta ilmestymisajankohtanaan. Fiktiivisen elokuvan ylivaltaa suomalaisessa elokuvan historiassa kuvaa hyvin Sedergrenin ja Kippolan muistutus siitä, että ensimmäinen Suomessa valmistunut pitkä värielokuva ei suinkaan ollut Toivo Särkän Juha, vaan Erkki V. Oksasen ohjaama Mi merten ja mannerten, molemmat vuodelta 1956 (s. 55). 16 mm:n värikääntöfilmille kuvatussa elokuvassa kuljetaan portugalilaisen tutkimusretkeilijän Fernão de Magalhãesin vuosina 1519-1522 tekemän maailmanympäripurjehduksen reittiä, tallennetaan maisemia ja seurataan ihmisten arkea ja juhlaa eri maanosissa. Elokuva ei saanut yhtä suotuisia arvioita kriitikoilta kuin Juha, mutta paljon puhuvaa on sen totaalinen unohtaminen elokuvahistoriasta.

\section{Niina Oisalo \\ YTM, M.A., mediatutkimus, Turun yliopisto}

\section{Lähteet}

Sedergren, Jari ja Kippola, Ilkka (2009) Dokumentin ytimessä: Suomalaisen dokumentti- ja lyhytelokuvan historia 1904-1944. Helsinki: Suomalaisen Kirjallisuuden Seura. 